\title{
Fonemy ś i ź w procesie różnicowania sztokawskiego obszaru językowego
}

\author{
PrZEMYSEAW BROM \\ Univerza v Bielskem-Biali, Fakulteta za humanistiko in družbene vede, Ul. Willova 2, \\ PL-43-309 Bielsko-Biała,pbrom@ath.bielsko.pl
}

\begin{abstract}
SCN II/1 [2009], 73-84
$\mathrm{Na}$ štokavskem dialektalnem območju še vedno potekajo procesi, ki povzročajo diferenciacijo posameznih jezikovnih standardov. Po razpadu Jugoslavije so se take aktivnosti povečale, ker so bili posamezni jeziki razglašeni za uradne jezike novonastalih držav. Fonema ś in $z ́$ sta pomemben primer diferenciacije črnogorskega jezika $v$ razmerju do ostalih jezikov, ki slonijo na štokavski dialektalni osnovi. Pred prevlado unifikacijskih teženj sta dobila oba fonema status dialektizmov. Ker se pogosto pojavljata na črnogorskem jezikovnem območju, bi ju bilo potrebno kot pomembna elementa vključiti v normo črnogorskega jezika. Prispevek obravnava pomembnost fonemov $s$ in $z$ v procesu diferenciacije standardov štokavskega jezikovnega območja.

In the area of the Štokavian dialect there have been processes aiming at diversifying particular language standards. These activities have gathered pace ever since the South-Slavic national community disintegrated. The Montenegrin area is characterized by the occurrence of developed forms of the phonological process of iotization - including the Jekavian. The products of that process - the phonemes $\dot{s}$ and $\dot{z}-$ existed in all Montenegrin dialects to a significant degree. Nowadays it is possible to classify them as important elements of the norm of the Montenegrin language because of their frequent occurrence in the contemporary language standard.
\end{abstract}

Ključne besede: jezik, standard, Črna gora, fonemi

Key words: language, standard, Montenegro, phonemes

Przemiany społeczno-polityczne, do których doszło w Europie w ciągu ostatnich kilku dziesięcioleci, doprowadziły do zmiany porządku ustalonego po zakończeniu II wojny światowej. Zmianom uległy dotychczasowe granice - wyznaczone nie w wyniku procesów etnicznych i kulturowych, lecz będące 
efektem konfliktów i kompromisów między siłami polityczno-gospodarczymi. Powstał problem budowania struktur młodych państwowości w warunkach różnorodności etnicznych, nierównych warunków gospodarczych i całego szeregu innych utrudnień - od działań międzynarodowych korporacji do konfrontacji współczesnych ideologii. Upadek systemów totalitarnych, postępująca integracja w strukturach Unii Europejskiej, procesy globalizacyjne a nawet rozwój współczesnych środków komunikacji - wszystkie te elementy wpływały na wzbudzenie wśród społeczeństw europejskich potrzeby tożsamości narodowej. Proces ten przebiega w sposób niezwykle ciekawy na słowiańskim obszarze językowym. Większość Słowian znajdowała się w XX. wieku w strefie wpływów systemów totalitarnych. Niestety, pozostawanie pod wpływem wspólnej ideologii ograniczało możliwości rozwoju poszczególnych narodów, zawsze bowiem oznaczała ona dominację silniejszego - nawet w ramach wspólnych struktur państwowych. Szczególna sytuacja miała miejsce na sztokawskim obszarze językowym - tam bowiem jednym z kompromisów niezbędnych do funkcjonowania państwa była potrzeba zdefiniowania wspólnego języka służącego do codziennej komunikacji. Wynikające z tego nieuwzględnianie potrzeb tożsamości poszczególnych narodów musiało $\mathrm{w}$ efekcie doprowadzić do przemian, których efektem jest dzisiejszy obraz społeczno-polityczny Bałkanów.

Na tym tle niezwykle ciekawa wydaje się być sytuacja językowa w Czarnogórze. Kraj ten bowiem, po długim okresie pozostawania w stanie politycznej i gospodarczej zależności, znajduje się obecnie na etapie uzyskiwania rzeczywistej niezależności. Pozwolę sobie przedstawić kilka faktów z najnowszej historii: po kilku wiekach względnej autonomii, wiek XX to w historii Czarnogóry okres pozostawania $\mathrm{w}$ ramach wspólnego systemu państwowego - po II wojnie światowej w Socjalistycznej Federacyjnej Republice Jugosławii. Idea zjednoczenia Słowian trafiła w Czarnogórze na niezwykle podatny grunt. Tendencje panslawistyczne uczyniły Czarnogórców naturalnymi sojusznikami komunistów w procesie tworzenia Jugosławii. Funkcjonująca w nowym państwie struktura federalna spowodowała podniesienie Czarnogóry do rangi republiki. Stała się ona jednocześnie beneficjentem znaczącej pomocy finansowej, która spowodowała przyspieszenie rozwoju kraju i jego industrializację. Rozwój był jednakże nierównomierny. Dopiero w latach 80-tych XX wieku wybrzeże czarnogórskie stało się znanym regionem turystycznym. Rozpad federacji jugosłowiańskiej postawił kraj w trudnej sytuacji. Po wyborach w 1990 roku znaczną siłą polityczną Czarnogóry stała się partia komunistyczna, popierająca rozpad federacji. Jednakże w przeprowadzonym w 1992 referendum niepodległościowym, 95,96 \% głosujących opowiedziało się za pozostaniem w związku z Serbią, z którą to Czarnogóra utworzyła wówczas nową Związkową Republikę Jugosławii. W 2003 Związkowa Republika Jugosławii przekształcona została w luźniejszy związek pod nazwą Serbia i Czarnogóra. Ustalono że po trzech latach każda z republik związkowych będzie miała prawo rozpisać referendum w sprawie niepodległości. 
21 maja 2006 odbyło się referendum niepodległościowe. Według Państwowej Komisji Wyborczej, 55,5 \% głosujących opowiedziało się za niepodległością Czarnogóry. Liczba głosów za secesją spełniła tym samym podwyższone wymogi stawiane przez Unię Europejską, konieczne dla uznania niepodległości państwa (próg 55 \%). Tak niewielka różnica (zaledwie 0,5\%) pokazuje jednakże jak złożona była sytuacja wewnętrzna kraju. 23 maja 2006 prezydent i premier Serbii uznali wynik referendum niepodległościowego. W kolejnych dniach akceptację deklaracji niepodległości ogłosiły w specjalnych oświadczeniach Unia Europejska oraz m. in. Albania, Bośnia i Hercegowina, Bułgaria, Chorwacja, Macedonia, Rosja i Stany Zjednoczone.

3 czerwca 2006 parlament kraju proklamował niepodległość. 28 czerwca 2006 Czarnogóra stała się 192 członkiem Organizacji Narodów Zjednoczonych. 17 października 2007 roku parlament uchwalił najnowszą, obowiązującą obecnie konstytucję Republiki Czarnogóry.

Uzyskanie przez Czarnogórę statusu podmiotu w stosunkach międzynarodowych nie rozwiązuje niestety problemu skomplikowanej sytuacji wewnętrznej kraju. Obecnie intensywnie podejmowane są próby sformułowania programu rozwoju świadomości narodowej Czarnogórców. Jest to bowiem proces najtrudniejszy w przypadku niewielkich narodów, które dodatkowo dłużej pozostawały elementem większego systemu państwowego i z tego powodu nie udało im się stworzyć systemu instytucji mających na celu kształtowanie tożsamości narodowej. Zagrożenie jest tym większe, im większą przewagę w strukturach państwa ma naród dominujący, dysponujący środkami prowadzącymi do narzucania swoich tradycji i polityki kulturowej. Bardzo często efektem tego jest asymilacja słabszego narodu, przy czym nierzadko odbywa się to przy wsparciu ze strony systemów oligarchicznych.

$\mathrm{Na}$ sztokawskim obszarze dialektalnym wciąż trwają bowiem procesy mające na celu różnicowanie poszczególnych standardów językowych. Działania te uległy znacznemu przyspieszeniu po rozpadzie południowosłowiańskiej wspólnoty państwowej, kiedy to poszczególne języki narodowe zostały ogłoszone językami urzędowymi. Wtedy to rozpoczęto powracanie do elementów charakterystycznych dla danego obszaru narodowego.

Jednym z najważniejszych elementów budowania wspólnoty narodowej jest istnienie jej języka literackiego. W przypadku bliskiego podobieństwa językowego sama jego nazwa odgrywa ważną rolę w procesie budowania więzi w grupie. Za niezwykle ważny uważa się psychologiczny aspekt wykorzystywania nazwy języka w szkołach, na ulicy, w domu i pracy, co kształtuje przekonanie o odmienności grupy. Podkreśla się również znaczenie symboli narodowych, flagi, godła, waluty, folkloru, wydarzeń sportowych i innych. Aby język stał się trwałym elementem zbiorowej świadomości, musi zostać spełniony szereg warunków. Jednym z nich jest istnienie publikacji potwierdzających jego proces standaryzacji. Do nich zaliczyć należy analizy historyczne, które w aspekcie diachronicznym i synchronicznym potwierdzają etnolingwistyczną odrębność języka, gramatykę, która stanowi naukową weryfikację jego stanu faktycznego, jak również publikacje regulujące zasady jego pisowni. Coraz częściej zwraca 
się również uwagę, iż w procesie różnicowania językowego niezwykle istotną rolę odgrywa istnienie określonego systemu leksykalnego, stanowiącego o odrębności danego języka.

Na tym tle współczesna sytuacja językowa na sztokawskim obszarze językowym jest niezwykle skomplikowana. Mamy bowiem do czynienia z sytuacją, w której po blisko dwóch stuleciach funkcjonowania wspólnego standardu serbsko-chorwackiego/chorwacko-serbskiego doszło do upadku idei wspólnego języka. Poszczególne narody dawnej Jugosławii po upadku wspólnoty państwowej wracały do swojej odmiany języka, nadając mu nazwę narodową i czyniąc urzędowym. Istnieje zatem wspólny, ogólnosztokawski system językowy, w ramach którego funkcjonują poszczególne standardy: bośniacki, chorwacki, czarnogórski i serbski, pełniące w poszczególnych krajach funkcje języków urzędowych.

Aparat pojęciowy w dziedzinie południowosłowiańskich języków literackich jest zróżnicowany, terminy w poszczególnych językach nie zawsze się ze sobą pokrywają. Językoznawcy południowosłowiańscy często wprowadzają swoje typy klasyfikacji. ${ }^{1}$ Charakterystyczne dla tego obszaru jest m.in. rozróżnienie pojęć standardni jezik (język standardowy) i narodni jezik (język narodowy). Standardni jezik to język neutralny, skodyfikowany, pozbawiony indywidualnych cech osobowych użytkownika. Ma charakter ogólny, jest w sposób selektywny przystosowany do wykorzystywania przez docelową grupę (społeczeństwo) i jako taki stanowi środek komunikacji. Natomiast narodni jezik jest silnie nacechowany stylistycznie, emocjonalnie, nieskodyfikowany - używany zarówno w mowie potocznej, jak i literaturze rozumianej jako sztuka słowa. Chociaż nie podlega bezpośrednio standaryzacji, nie oznacza to, że nie zawiera w sobie elementów normy językowej. Jest swego rodzaju syntezą elementów normatywnych i nienormatywnych, tworem bogatszym, bo nie poddawanym nieustannemu wpływowi czynników kodyfikacyjnych.

Struktura języka czarnogórskiego obejmuje przede wszystkim elementy strukturalne ogólnej, szerokiej, ponadnarodowej normy sztokawskiej, wspólnej dla języków: chorwackiego, serbskiego, bośniackiego i czarnogórskiego. ${ }^{2}$ Dla tych narodów stanowią one element wspólny, łączący - nie będący przeszkodą $\mathrm{w}$ procesie wzajemnej komunikacji. Jednocześnie w systemie językowym istnieje norma szczególna, powstała spontanicznie podczas naturalnej standaryzacji - procesie o charakterze socjolingwistycznym. Stanowią ją liczne elementy o charakterze interdialektalnym lub ponaddialektalnym, a które zostały już częściowo skodyfikowane jako standardowe w publikacjach ostatnich kilkunastu lat. ${ }^{3} \mathrm{O}$ ich dużym znaczeniu decyduje dyferencja - są one elementem charakterystycznym wyłącznie dla języka czarnogórskiego i odróżniającym go

\footnotetext{
${ }^{1}$ Por. D. Brozović: Standardni jezik. Teorija, usporedbe, geneza, povijest, savremena zbilja. Zagreb, 1970.

${ }^{2}$ Por. Nikčević 1997b.

${ }^{3}$ Por. Nikčević 1993b: 8.
} 
od pozostałych języków obszaru sztokawskiego i szerzej - od innych języków słowiańskich.

Trzecim elementem systemu języka czarnogórskiego - o najmniejszym zakresie występowania - jest grupa regionalnych zjawisk językowych, które nie weszły w skład szeroko rozumianej normy czarnogórskiej i pozostały elementem literatury i historii języka narodowego. Ich brak przynależności do współczesnego standardu czarnogórskiego nie oznacza jednak, że stanowią element obcy temu językowi. Przeciwnie, procesy normatywne w języku czarnogórskim nie zostały jeszcze zakończone i wiele elementów staje się częścią składową rozwijającej się normy językowej.

Znaczącym elementem trzeciej grupy zjawisk językowych są zasoby leksykalne należące do narodowego języka czarnogórskiego. To one stanowią najdobitniejsze potwierdzenie jego odrębności w stosunku do pozostałych standardów sztokawskich. Pomimo istnienia wszystkich podstawowych publikacji opisujących współczesny standard czarnogórski: historii języka, gramatyki i zasad pisowni, nie został jeszcze opublikowany słownik. Istnieje wiele przyczyn takiego stanu rzeczy. Język czarnogórski został ogłoszony urzędowym w najnowszej konstytucji proklamowanej 19 października 2007 roku, wcześniej funkcję tą pełnił język serbski wymowy ijekawskiej. Nie istniały więc warunki ku temu, by prace nad słownikiem języka czarnogórskiego zostały rozpoczęte. Wyjątkiem są pomniejsze publikacje poszczególnych badaczy, nie będące jednakże elementem większego wspólnego projektu. Obecnie prace nad słownikiem trwają, wydaje się jednakże, że sama jego publikacja jest kwestią stosunkowo odległą. Opracowanie wielotomowego słownika wymaga ogromnej pracy zespołowej, dużych nakładów finansowych i przede wszystkim jest procesem niezwykle czasochłonnym.

Czarnogórskie środowiska naukowe postulują więc rozpoczęcie w pierwszej kolejności prac nad opublikowaniem Stownika charakterystycznej leksyki czarnogórskiej. Miałby on zawierać zasoby leksykalne narażone obecnie na silne procesy archaizacji prowadzące w efekcie do ich całkowitego wyeliminowania z systemu języka. Publikacja ta stanowiłaby w istocie kompletną klasyfikację montenegryzmów, które definiują tożsamość językową i narodową Czarnogórców. Argumentem przemawiającym za realizacją tego projektu jest fakt rzeczywistego występowania narodowej leksyki na terytorium Czarnogóry. Wśród przeciwników pojawia się najczęściej teza o jej nieprzynależności do współczesnego standardu językowego. Tą argumentację warto zatem poddać krótkiej analizie. Każdy język standardowy jest obecnie poddawany wpływom elementów pozanormatywnych. To właśnie otwartość języka na nowe elementy umożliwia jego rozwój. W tym przypadku przedmiotem sporu są czarnogórskie prowincjonalizmy i regionalizmy, które mogą wzbogacić system leksykalny nie naruszając jednocześnie jego podstawowej struktury. Kwestia, czy dany element należy do normy językowej, czy nie, musi być jednakże rozpatrywana w szerszej perspektywie. Współczesną normę stanowi bowiem wspominany już ponaddialektalny, ogólnosztokawski system, wspólny dla języków chorwackiego, serbskiego, czarnogórskiego i bośniackiego. Jednakże elementy posiadające 
status dialektalny w jednym ze standardów niekoniecznie muszą posiadać taki sam status w drugim. W świetle tego błędem jest analizowanie danego zjawiska językowego w ten sam sposób w ramach dwóch różnych struktur. Jeśli dany leksem poddać analizie poza czarnogórskim terytorium językowym, nie można mu przypisać niczego więcej, niż bycie elementem o charakterze dialektalnym. Natomiast w ramach struktury standardu czarnogórskiego będzie on po prostu elementem systemu leksykalnego.

Kwestią odmienną jest natomiast pytanie o źródła leksyki będącej treścią planowanej publikacji. Proponuje się, aby były nimi po pierwsze teksty czarnogórskie pochodzące z okresu sprzed wprowadzenia reformy Vuka Karadžicia, tj. z lat 1360-1830. Wtedy to bowiem język czarnogórski przeżywał okres swojego największego rozwoju. Elementy języka narodowego stanowiły wtedy istotną część twórczości (przekazywanej zarówno w formie ustnej jak i pisemnej), sam zaś język podlegał procesom utrwalania w świadomości swoich użytkowników. Późniejszy okres również bogaty był w dzieła mogące służyć jako doskonałe źródło leksyki czarnogórskiej. Jest to twórczość Petara II. Petrovicia Njegoša, Stefana Mitrova Ljubišy czy Marka Miljanova Popovicia, przede wszystkim zaś Gorski vjenac Njegoša - największe dzieło literatury czarnogórskiej zawierające niezliczoną ilość słownictwa charakterystycznego dla tego języka. ${ }^{4}$ Różnice w systemie leksykalnym na obszarze sztokawskim w XIX wieku udowadniał sam Vuk Karadžić w swoim Srpskom rječniku z 1818 i 1852 roku. Wyróżnia on w nim liczne formy rdzennie czarnogórskie, określając je jako elementy z ,dialektu południowego”.

$\mathrm{Na}$ obszarze narodowego języka czarnogórskiego, zdominowanym przez wymowę ijekawską, szeroko występują elementy będące efektem procesów jotowania. Są nimi m.in. głoski ś i $z ́$ charakterystyczne dla wszystkich dialektów czarnogórskich. Fonemy te są elementem codziennej komunikacji na terenie Czarnogóry. Istnieje jednakże niewiele tekstów pisanych powstałych w ciągu ostatnich kilku dziesięcioleci, w których one występują. Powodów takiego stanu rzeczy jest kilka. Za główny uznać można trwające przez cały wiek dwudziesty procesy asymilacyjne, których celem było jak największe ujednolicenie poszczególnych języków narodowych w ramach ówczesnego standardu serbsko-chorwackiego / chorwacko-serbskiego.

Od czasów reformy Vuka Karadžicia za właściwe uważane były wyłącznie formy należące do ogólnej, ponadnarodowej sztokawskiej normy językowej. W związku z tym elementy narodowej normy czarnogórskiej posiadały wyłącznie status dialektalny. W latach 90 -tych XX. wieku, kiedy poszczególne narody post-jugosłowiańskie powracały do swoich wariantów językowych, w Czarnogórze - pozostającej w federacji politycznej z Serbią - językiem urzędowym wciąż pozostawał serbski wymowy ijekawskiej. Czarnogórscy pisarze i publicyści nie używali form pochodzących z języka narodowego, będąc zmuszonymi do poddania się zasadom pisowni wspólnej normy, czasami też z bardziej pro-

${ }^{4}$ Ž. Đurović: Narodni karakter Njegoševa jezika. Lučindan, Cetinje 2001, 29-30. 
zaicznych powodów - preferowane było wtedy tworzenie w dialekcie ekawskim, niedostosowanie się do tego uniemożliwiało niejednokrotnie uzyskanie zgody na publikację dzieła. Nie bez znaczenia był również dialektalny status form czarnogórskich - twórcy chcieli uniknąć wykorzystywania elementów spoza normy językowej i wynikającego z tego obniżenia statusu literackiego dzieła.

Dubravko Škiljan, opisując znaczenie fonemów ś i $z$ dla języka czarnogórskiego pisał: „Najbliższy temu, aby uznać go za odrębny język nie jest chorwacki, lecz czarnogórski - w momencie kiedy do standardu językowego wprowadzone zostaną miękkie $\check{s}$ i $\check{z}$ jako osobne fonemy (..), zostanie dokonany bardziej zdecydowany krok niż wszystkie zmiany wprowadzone tutaj $\mathrm{w}$ celu różnicowania języka. Ponieważ jest to element zdecydowanie definiujący strukturę języka, liczba lub system fonemów" (Škiljan 1996: 41). Stanowisko przeciwne reprezentuje Drago Čupić, pisząc: „Upór niektórych intelektualistów przy języku czarnogórskim oparty jest nie na rzeczywistych cechach językowych, lecz na cechach różnicujących jeden językowy sposób wyrażania od drugiego w ramach języka serbskiego. Jeśli zostałyby zaprezentowane różnice lingwistyczne a nie dialektalne, ich stanowisko nie musiałoby być poddawane w wątpliwość, lecz takie różnice nie istnieją; nawet na poziomie język serbski : język w Czarnogórze. Różnice znajdują oni w dialektalnych głoskach $s ́, z ́$ i $d z$, oraz w części leksyki. Jeśli chodzi o występowanie głosek $s^{\prime}, z$ i $d z$, należy wspomnieć, iż te pierwsze występują we wszystkich dialektach ijekawskich obszaru sztokawskiego, tak więc zarówno u Muzułmanów jak i u sztokawskich Chorwatów i jako takie nie mogą stanowić powodu do tworzenia osobnego języka czarnogórskiego. Pojawiają się one wszędzie tam, gdzie występuje dialekt ijekawski, nie są jednakże fonemami, tzn. nie są nośnikami znaczenia ..." (Ćupić 2002: 21). Obydwa te stanowiska stanowią doskonały przykład złożoności sytuacji językowej w Czarnogórze.

Jedna $z$ tez postawionych przez Čupicia nie może zostać poddana w wątpliwość - głoski ś i ź rzeczywiście występują również poza terytorium dzisiejszej Czarnogóry. Najważniejsza jest jednakże kwestia statusu jaki posiadają one we współczesnych standardach sztokawskich. Poza czarnogórskim obszarem językowym fonemy te występują w niewielkim zakresie a ilość leksemów, w których są realizowane jest ograniczona. Dlatego we współczesnym języku bośniackim, chorwackim czy serbskim mają one wyłącznie charakter dialektalny. Za tak zdefiniowanym ich statusem przemawia również kwestia ich pochodzenia - ich pojawienie się na terytorium wyżej wymienionych języków spowodowane było migracjami ludności z terytorium Czarnogóry. ${ }^{5}$ Tymczasem w dialektach czarnogórskich występują one bardzo szeroko a w języku mówionym niezwykle rzadko zastępowane są przez sj i zj. Z tego właśnie powodu należy je traktować jako nierozłączny element systemu języka czarnogórskiego.

\footnotetext{
${ }^{5}$ Por. Skerlić 1955: 87.
} 
Najnowsze opracowania gramatyczne uznają fonemy ś i ź za trwały element normy języka czarnogórskiego. Opiera się to na założeniu iż współczesne standardy bośniacki, chorwacki, czarnogórski oraz serbski tworzą wspólny sztokawski system językowy, jednakże elementy posiadające status dialektalny w jednym ze standardów niekoniecznie muszą posiadać taki sam status w drugim. W świetle tego błędem jest analizowanie danego zjawiska językowego w ten sam sposób w ramach dwóch różnych struktur. Jeśli wspomniane fonemy poddać analizie poza czarnogórskim terytorium językowym, nie można im przypisać niczego więcej, niż bycie elementem o charakterze dialektalnym. Natomiast w ramach struktury standardu czarnogórskiego są po prostu one dwoma spośród 33 elementów systemu fonetycznego.

Szerokie występowanie pozwala na zakwalifikowanie tych głosek jako część standardu czarnogórskiego, zaś analiza par leksemów pozwala przypisać im funkcję dystynktywną, jak np. w parach: śenka : Senka, źenica : ženica; śeka : seka; Koźa : koža i inne. Jednocześnie nie ma możliwości zastąpienia fonemu $s$ w każdym przypadku przez $s j$, jak to sugerują niektórzy badacze. Czarnogórskie $s$ nie jest bowiem wyłącznie wynikiem procesu jotowania głoski $s$-dowodem są niektóre antroponimy: Maśo, Veśo, Muśo, Daśko, Puśo i inne. Często zwraca się również uwagę na różnorodność występowania fonemów ś i ź; pojawiają się zarówno w nagłosie, np. źena, źenica, Źagora, źato, źalo, źakati, śutra, śen, śenina, śenka, śever, śeverika, śenokos, śenčiti, śetiti, śesti, śeđeti, śajiti, śajan, śera, śaktati, śakćeti, śeme, śéci, śekira, śedište, śednik, śednica, śok itd.; w śródgłosie: ośe, klaśe, ośećaj, uśeđelica, iźesti, iźeden, koźi, koźavina, prośek, prijeśek, prośed, paśi, paśaluk, pośed, suśed, prośak, pośeći, kiśelina, kośćela, uśeka, ośeći, kiśelica, jak i w wygłosie: muś, guś, iś, miś, galeś, jeleś, maiś, poś.

Częstotliwość występowania ś i ź udowadnia Vukić Pulević w swojej publikacji o czarnogórskiej toponimii. ${ }^{6}$ Wieloletnie badania i ilość zgromadzonych toponimów pokazują dużą frekwentywność tych głosek w systemie języka czarnogórskiego. Potwierdza ją również opublikowany w 2003 roku słownik nazw rośli i zwierząt. Znaczenie fonemów ś i $z ́$ w procesie różnicowania językowego współczesnych standardów sztokawskich jest więc ogromne - stanowią bowiem potwierdzenie odrębności standardu czarnogórskiego w stosunku do bośniackiego, chorwackiego i serbskiego.

Do niedawna przedmiotem dyskusji pozostawała kwestia zapisu $s$ i ź w języku czarnogórskim. Obowiązujące alfabety - zarówno abeceda jak i azbuka - nie posiadały grafemów odpowiadających tym głoskom. Dlatego też twórcy czarnogórscy używali różnorodnych odpowiedników na ich określenie: obok

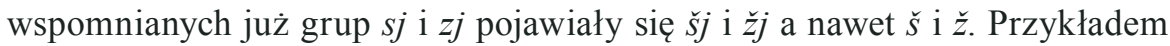
mogą być chociażby Stefan Mitrov Ljubiša czy Vuk Vrčević, u których znajdujemy następujące leksemy: šjela, šjednik, pašje, šjena, šjeta, šjen, pošjeći,

\footnotetext{
${ }^{6}$ Por. Pulević 2005.

${ }^{7}$ Por. Pulević, Samardžić 2003.
} 
šjeme, šjesti, šjajno, našjedne, pošjede, prošjela, šjenokos, sušjed, gušjenica, šjejati, kišjelica, glavošječni i inne. W tym przypadku grafem šj występuje w miejsce brakującego ś. Późniejsi redaktorzy dostosowujący dzieła do aktualnych ortografii często zamieniali $\breve{s} j$ na $s j$, ostatecznie wypaczając pierwotne znaczenie leksemów. Jednakże już pod koniec XIX. wieku pojawiły się propozycje, by wprowadzić do użycia wzorowany na polskim grafem ś. Ostatecznie do czarnogórskiego standardu grafemy te wprowadził Vojislav Nikčević. W swoim Pravopisie poświęcił on fonemom ś i ź osobny rozdział, podkreślając tym samym ich znaczenie w procesie standaryzacji języka czarnogórskiego. Obecnie nowe zasady zyskują coraz więcej zwolenników - powstają bowiem liczne teksty tworzone zgodnie z zasadami pisowni opracowanymi przez Nikčevicia.

Częstotliwość występowania i neutralność stylistyczna fonemów $s ́$ i $z ́$ są najważniejszymi argumentami za ich wprowadzeniem do współczesnej normy języka czarnogórskiego. Jako zjawisko typowe dla jednego języka, głoski te stanowią o odrębności czarnogórskiego w stosunku do pozostałych standardów post-serbo-chorwackich, potwierdzają bowiem istnienie między nimi strukturalnych różnic. Ich unormowanie we współczesnym standardzie czarnogórskim jest kolejnym krokiem w kierunku stabilizowania sytuacji na sztokawskim obszarze dialektalnym.

Naród czarnogórski, pomimo ponad tysiącletniej tradycji państwowej, wielowiekowym tradycjom i odrębności etnicznej, przez długi czas znajdował się pod naciskiem polityki asymilacyjnej. Równocześnie Czarnogóra przez wiele wieków z sukcesami prowadziła obronną walkę z obcymi siłami pod hasłami stworzenia wspólnego, wielkiego państwa na Bałkanach. Wokół tych ideałów powstała swego rodzaju wspólnota duchowa podparta wielką liczbą dzieł literackich powstałych w celu jej wspierania. Dominującą inspiracją było również wyznanie prawosławne. Powstał niezwykle silny mit narodowy, który został skonfrontowany z realiami politycznymi. Demograficznie i ekonomicznie silniejsi sąsiedzi przypisywali Czarnogórze i jej mieszkańcom rolę opozycyjną. Niewielki naród, przez wiele wieków walczący z większym i silniejszym wrogiem stał się ofiarą własnych ideałów.

Przez cały wiek XX Czarnogóra ze swoim przywiązaniem do Serbii pozostawała w swego rodzaju letargu. Obecnie, w dwa lata po zadeklarowaniu w referendum narodowym niepodległości, proklamowaniu jej przez parlament oraz uznaniu Czarnogóry za niepodległe państwo przez instytucje międzynarodowe, Czarnogórcy praktycznie realizują marzenie o powrocie do własnej państwowości. Kwestie języka, jego statusu prawnego i procesów normatywnych w nim zachodzących stanowią niezwykle ważny element tych działań. Publikacje opisujące narodową leksykę stanowią zatem kolejny krok na drodze do wzmacniania i kształtowania tożsamości językowej narodu czarnogórskiego. 


\section{BIBLIOGRAFIA}

Przemysław BROM, 2007: Czarnogórski standard wobec różnicowania językowego południowej Słowiańszczyzny. Bielsko-Biała: Wydawnictwo ATH.

Crnogorski jezik u javnoj upotrebi. Zbornik saopštenja s okruglog stola. Podgorica: Crnogorski PEN Centar. 2002.

Crnogorski jezik bio bi najbolje rješenje. Pobjeda, 21. 10. 2006.

Drago ĆUPIĆ, 2002: Ne postoji poseban crnogorski jezik. D. Ćupić, E. Fekete, B. Terzić: Slovo o jeziku, Jezički poučnik, knj. 2, Beograd.

Hanna DALEWSKA-GREŃ, 2002: Języki słowiańskie. Warszawa: Wydawnictwo Naukowe PWN.

Žarko ĐUROVIĆ, 2004: Crnogorski književni/standardni jezik u dijahroniji i sinhroniji. Štokavski književni jezici u porodici slovenskih standardnih jezika. Podgorica: Crnogorski PEN centar.

Jezici kao kulturni identiteti na području bivšega srpskohrvatskoga ili hrvatskosrpskoga jezika. Cetinje: Crnogorski PEN centar. 1998.

Jezik kao domovina. Deklaracija Crnogorskog PEN centra o ustavnom položaju crnogorskog jezika. Doclea, br. 3. Podgorica. 1994.

Miloš KOVAČEVIĆ, 2001: Jedan ili tri jezika? Lingvistički nazivi na srednjojužnoslavenskom području. Jezik i demokratizacija (Zbornik radova). Sarajevo.

Halina KURKOWSKA, 1977: Polityka językowa a zróżnicowanie społeczne współczesnej polszczyzny. Socjolingwistyka 1. Katowice.

Jerzy MOLAS, 2005: Chorwacka dyskusja o statusie i nazwie języka. Studia z Filologii Polskiej i Stowiańskiej nr 40\2005. Warszawa.

Milorad NIKČEVIĆ, 2004: Ogledi / studije / susreti. Apologetika crnogorskog jezika. Osijek: HCDP Croatica-Montenegrina RH.

Vojislav NIKČEVIĆ, 1993a: Crnogorski jezik. Geneza, tipologija, razvoj, strukturne odlike, funkcije. Cetijne: Tom I, Matica crnogorska.

- -, 1993b: Piši kao što zboriš. Glavna pravila crnogorskoga standardnoga jezika. Podgorica: Crnogorsko društvo nezavisnih književnika.

--, 1997a: Crnogorski jezik. Geneza, tipologija, razvoj, strukturne odlike, funkcije. Cetinje Tom II Od 1360 do 1995 godine, Matica crnogorska.

- -, 1997b: Crnogorski pravopis. Cetinje: Crnogorski PEN centar.

- -, 1994: Status i problemi crnogorskog jezika. Doclea, br. 2. Podgorica.

Norma i kodifikacija crnogorskog jezika. Zbornik radova. Institut za crnogorski jezik i jezikoslovlje. Cetinje. 2005.

Barbara OCZKOWA, 2002: Wpływ polityki językowej w Jugosławii na normę języka chorwackiego. Bulletin de la société polonaise de linguistique. Fasc LVIII 2002. 
- -, 1999: Zagadnienia sporne w językoznawstwie chorwackim i serbskim po rozpadzie języka serbsko-chorwackiego. Przemiany w świadomości i kulturze duchowej narodów Jugosławii po 1991 roku. Kraków.

Vuk Pulević, Novica Samardžić, 2003: Fitonimi i zoonimi u toponimiji Crne Gore. Podgorica: Dukljanska akademija nauka i umjetnosti, Odjeljenje za književnost i jezik.

- -, 2005: Glasovi ś i ź u crnogorskoj toponimiji. Zbornik radova sa naučnoga skupa Norma i kodifikacija crnogorskoga jezika. Cetinje: Institut za crnogorski jezik i jezikoslovlje.

Ferdinand ROSI-LANDI, 1982: Jezik kao rad i kao tržište. „Rad” Belgrad.

Jovan Skerlić, 1955: Istočno ili južno narečje. Pisci i knjige, III. Beograd: Prosveta.

Agnieszka SPAGIŃSKA-PRUSZAK, 2005: Język-naród-państwo (dylematy językowe narodów Jugosławii). Riječ, 11/1. Rijeka.

- -, 1997: Sytuacja językowa w byłej Jugosławii. Gdańsk: Wydawnictwo Uniwersytetu Gdańskiego.

Dubravko ŠKILJAN, 1996: Moć jezika (wywiad). Vreme, br. 304, Beograd, 17. sierpnia 1996. 41.

Emil TOKARZ, 2002: Dynamika rozwoju języków słowiańskich końca XX w. $N a-$ rodowy i ponadnarodowy model kultury. Europa Środkowa i Pólwysep Bałkański. Red. B. Zieliński. Poznań: Wyd. Naukowe PAN.

- -, 1998: Mikrojęzyki słowiańskie - problemy badawcze językoznawstwa porównawczego. Nowe czasy, nowe języki, nowe (i stare) problemy. Katowice.

- -, 1992: Mit wspólnoty Słowian południowych i jego konsekwencje (na przykładzie narodów dawnej Jugosławii). Rozpad mitu i języka? Katowice.

- -, 2001: Współczesne standardy językowe dialektów sztokawskich. Języki słowiańskie dziś. Nowe fakty. Nowe spojrzenia. Katowice.

\section{FONEMA Ś IN Ź - SPREMEMBE V ŠTOKAVSKEM JEZIKOVNEM PROSTORU}

Na štokavskem dialektalnem območju še vedno potekajo procesi, ki povzročajo diferenciacijo posameznih jezikovnih standardov. Po razpadu Jugoslavije se je začelo vračanje k elementom, ki so značilni za posamezna narodna območja. Za črnogorsko območje (tudi jekavsko) je značilna jotacija. Rezultati so razvidni v vseh črnogorskih dialektih. Stanje se do danes ni spremilo kljub številnim poskusom poenotenja od Vuka Karadžića do konca 20. stoletja. Jezikovna poenotenja so v 20. stoletju upoštevala samo oblike, ki so pripadale skupnemu štokavskemu standardu. Posledica tega je izločitev tipičnih elementov posameznih narodnih jezikov iz skupnega sistema. Obstaja le malo besedil 20. stoletja, ki vsebujejo omenjene oblike, saj je za uradni jezik Črne gore bila razglašena srbščina. Z neodvisnostjo so v Črni gori nastali pogoji, ki omogočajo kodifikacijo črnogorske norme in sprejetje splošno rabljenih črnogorskih oblik kot delov jezikovne

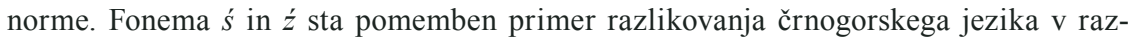


merju do ostalih jezikov, ki izhajajo iz štokavske dialektalne osnove. Med jezikovnim poenotenjem sta dobila oba fonema status dialektizmov - ker se pogosto pojavljata na črnogorskem jezikovnem območju, bi ju bilo potrebno kot pomembna elementa vključiti v normo črnogorskega jezika. 